\title{
NEW VARIATION OF INDONESIAN HUMOR USING LANGUAGE EXPERIENCE
}

\author{
Rawuh Yuda Yuwana*, Riyadi Santosa, Sumarlam \\ Pascasarjana, Universitas Sebelas Maret, Indonesia \\ *Corresponding author: yuda.ryy@gmail.com
}

\begin{tabular}{ll}
\hline INFORMASI ARTIKEL & \multicolumn{1}{c}{ ABSTRAK } \\
\hline Sejarah Artikel & Tujuan dari penelitian ini adalah untuk menemukan variasi baru humor \\
Diterima: $6 / 8 / 2018$ & Indonesia menggunakan pengalaman bahasa. Penelitian ini adalah \\
Direvisi: $3 / 6 / 2019$ & penelitian deskriptif-kualitatif. Mengumpulkan data menggunakan \\
Disetujui: $10 / 6 / 2019$ & metode mendengarkan dengan menggunakan teknik dasar sadap - catat. \\
Tersedia Daring: $30 / 6 / 2019$ & $\begin{array}{l}\text { Analisis data dalam penelitian ini menggunakan metode referensi } \\
\text { penyamaan dengan menggunakan teknik perbandingan untuk }\end{array}$ \\
Kata Kunci: & mendukung kodifikasi, reduksi, presentasi, dan interpretasi seperti \\
Strategi Humor & desain kerja penelitian kualitatif. Sumber data adalah video dan meme. \\
Variasi Humor & Hasil penelitian ini, komedian menggunakan 8 strategi dalam bahan \\
Humor Indonesia & humornya, yaitu: (1) mengeksploitasi kebenaran umum yang sudah \\
Pengalaman Bahasa & diketahui orang; (2) mengubah konstituen dengan pengalaman \\
& bahasanya; (3) sengaja menempatkan kata ganti yang salah; (4) \\
& menyampaikan sesuatu yang tidak lengkap; (5) mengalihkan berbagai \\
bahasa; (6) memberikan respons yang tidak terkait sama sekali; (7) \\
mengeksploitasi celah bahasa untuk mendistorsi maknanya; (8) \\
menyampaikan sesuatu yang tidak wajar, absurd, bahkan terkesan \\
kontroversi.
\end{tabular}

\section{ABSTRACT}

Keywords:

Humor Strategy

Humor Variation

Indonesian Humor

Language Experience
The purposes of this research is to find new variation of Indonesian humor using language experience. This research is a descriptivequalitative research. Collecting data uses listening method by using basic technique of tap and then write. Analyzing data in this research uses equalizing reference method by using comparing technique to support codification, reduction, presentation, and interpretation such as work design of qualitative research. Source of data base on videos and memes. The results of this research, comedians use 8 strategies in his humor materials, those are: (1) exploiting the common truth that people already know; (2) changing constituents with his language experience; (3) putting false pronouns deliberately; (4) conveying something incomplete; (5) diverting different languages; (6) providing an unrelated response at all; (7) exploiting the language gap to distort its meaning; (8) conveying something unnatural, absurd, even impressed controversy.

Copyright@2019, Rawuh Yuda Yuwana, Riyadi Santosa, Sumarlam This is an open access article under the CC-BY-3.0 license
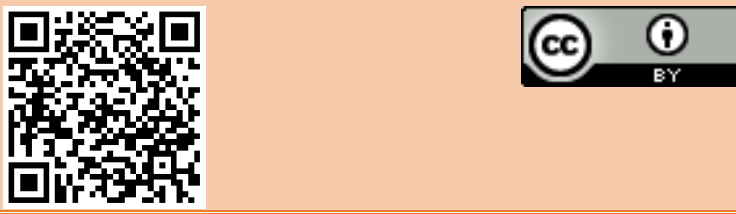


\section{INTRODUCTION}

The quality of the humor creation depends on the intelligence and creativity of the speaker or writer in searching gaps of meaning a word. This is important because a humor that commenting the physical form does not educate, so a smart and a creative humor by playing the meaning of a word without cornering the other becomes more interesting. Suhadi (1989) said that humor will present a funny thing, depending on the selection of sounds/intonations, meanings, and contradictions or misappropriation of certain rules, customs or cultures. The general structure are; orientation is the opening of humor material that introduces the thing to be highlighted, event is the explanation of the occurrence of an event in the series of humor material, then twist is the ending or end of a story that is usually deliberately twisted or deflected to get funny. This research focuses on how a comedian takes advantage of the leniency and the possibility of a word and then raises more than one meaning. In this case, the deviation of meaning can affect the constituent change in the sentence.

This research uses the theory of linguistic humor. Soedjatmiko (1992) divides the two linguistic theories of humor, the theory of semantic humor and the theory of pragmatic humor. The semantic theory of humor utilizes ambiguity by contrasting the first meaning distinct from the second meaning. Meanwhile, the pragmatic theory of humor utilizes deviations from the principles of word acting. The purpose of this study is to find constituent changes in humor, so this study does not use pragmatic theory in its analysis.

There are two kinds of humor according to Rohmadi (2010), namely verbal and nonverbal humor. Verbal humor is a humor that is represented by words of writing or speech. Nonverbal humor is with gestures or images, for example in pantomime or caricature. Verbal humor can be researched linguistically because the constituent elements form a playing of word. Furthermore, the phrase originally understood can be transformed into an absurd experience.

In humor, meaning is an element of language that is often used by speakers or writers in constructing humor. This happens because of the flexibility and the number of opportunities to interpret the word. Meaning has a large area, as proposed Poerdawarminta (2002), meaning is some possible meaning that has not been very clear. Unclearness can occur because of the large number of unity of meaning contained in a particular word and because of the constraints provided by the component relationships of the unity of a particular word meaning.

Introduced by Halliday, Matthiessen, and Halliday (2014) that systemic functional linguistic theory is divided into three main functions, namely ideational, interpersonal, and textual. Ideational uses language to express experience in experiential meaning encoding logical experiences and meanings that reflect logical relationships. Interpersonal uses language to encode interactions, showing how defensive, proposing, encoding about obligations and trends, and expressing attitudes. Textual uses language to organize experience, logical and interpersonal meaning into a coherence in speech and writing language. Ideational meanings encompass a transitivity system that is understood as a process and understands it at the level of clause analysis. Ideational function is said to be a function of language because through this function, both speakers and writers are tied to their experience and relationships with the phenomena of the world (Tiani, 2017).

Emphasized by Halliday (1985) that internal experience is in consciousness, reaction, understanding, and perception, in addition to its linguistic actions in speaking and understanding. Furthermore, transitivity is a system that describes experience as a kind of process associated with participants and circumstance. In describing the type of process selected in each clause, each clause is related to the different participant roles, which are classified as actor, senser, behaver, sayer, extent and carrier. In the process the meaning can be understood at the clause level consisting of: (1) process, (2) participants, and (3) circumstance. The process refers to the activity that occurs in the clause. In traditional and formal grammar is called verbs. 
Participants are people or objects involved in the process. Circumstance are an environment where the process involves participants, because the core of experience is the process, then in the clause level, the process of determining the number and category of participants. In addition, the process indirectly determines circumstance. Therefore, at the level of clause analysis, the center of meaning exists in the process (Mujianto, 2018).

In the transitivity study with the LSF approach, experience realized with clauses is constructed from three constituents. First, the process/event is realized in the grammatical function of the predator in the form of a verb group. Second, the participants are realized in the subject and complement with the form of the noun group. Third, circumstans are realized in adjuncts with noun group shapes, preposition phrases, or adverbs. Furthermore, the thing to note is the concept of humor builder and the embodiment of experience in constituents as a clause builder.

The result of some previous researches related to the study; Firmansyah (2017) examine the language representation of humor in the Stand Up Comedy event on Metro TV, Marwan (2013) examines the use of humor in Alain Le Saux's book, Fauzan (2015) examines the use of transitivity in TV One's text, and Juramli (2016) examines the dominance of the transitivity system in the Daqaaiqul Akhbar text. Finally, their researches that have same focus on humor but not in transitivity, and the other researches that focus on transitivity but not in humor, so their studies in humor related to deviations of meaning and constituent change to the extent that the writer has not been found yet.

The purpose of this research is to find new variations of Indonesian humor material. Therefore humor theory is needed to mark clauses that contain humor and not. Furthermore, the theory of linguistic functional systemic that is more focused on the theory of transitivity will be used to find the constituent changes made by comedians with the experience of language.

\section{METHOD}

There are four keyword research methods that need to be considered are the scientific way, data, purpose, and usability. Research methods are needed in achieving research objectives because the methods that formulate ideas and thoughts are based on a scientific approach. The method used in this research is descriptive qualitative method. This is because the data analyzed is not in the form of numbers, symbols or coefficients about inter-variable relationships. Qualitative methodology as a research procedure that produces descriptive data in the form of written or oral words of people and behavior that can be observed. This approach is directed to the background and the individual holistically (Sugiyono, 2014), (Aminuddin, 1990), (Moleong, 2013).

Data and sources of data in this study are determined based on needs in research problems. The data in this research is a clause of humor which contains deviations of meaning and constituent change. This study will not retrieve data from one source for a certain period of time. This research will retrieve data from several sources such as: meme, clusters, ILK, and Stand-up comedy. The thing that needs to be emphasized is the source of television viewing data, will be taken some as a representative. The data were collected using the method refer to basic tapping technique and advanced technique note. The use of the method in referring to the provision of data is manifested in the basic techniques of tapping and the advanced technique of note is not a separate process (Mahsun, 2014). The data are analyzed by referential reference method by appealing technique (Mahsun, 2014), that is comparing deviations of meanings and constituent changes with referents to support codification, data reduction, data presentation, and interpretation in accordance with qualitative research frameworks (Sugiyono, 2014). 


\section{RESULT AND DISCUSSION \\ Process - Participant}

In this data shows comedian strategies and constituent changing between process and participant for a same word in Indonesian but has different aim and meaning.

(1.1) "Jangan suka ngurusi orang lain, karena belum tentu orang itu ingin kurus." ("Don't like to take care of other people, because not necessarily the person wants to be thin.")

C1: Jangan suka ngurusi orang lain, proses material

(Don't like to take care of other people,) (material process)

C2: karena belum tentu orang itu ingin $\underline{\text { kurus. }}$. verbiage

(because not necessarily the person wants to be thin.) (verbiage)

Suhadi (1989) said that humor will present a funny thing, depending on the selection of sounds/intonations, meanings, and contradictions or misappropriation of certain rules, customs or cultures. The general structure are; orientation is the opening of humor material that introduces the thing to be highlighted, event is the explanation of the occurrence of an event in the series of humor material, then twist is the ending or end of a story that is usually deliberately twisted or deflected to get funny. In the data (1.1) the comedian advises not to interfere or think about the affairs of others by using the word "ngurusi" (take care). The comedian has made sure the meaning of the word "ngurusi" (take care) will be interpreted by "ikut campur" (interfering), because the context of the sentence directs the word "ngurusi" (take care) to that meaning. However, the comedian immediately and suddenly changed the word "ngurusi" (take care) with the reference "membuat menjadi kurus" (make be thin). The comedian exploits the possibility of forming the word "ngurusi" (take care) which can be formed from the basic "urus" (take care) and "kurus" (thin).

Based on Halliday (1985) which emphasizes that internal experience is in consciousness, reaction, understanding, and perception, in addition to its linguistic actions in speaking and understanding. Further detailed in the theory of transitivity as a system that describes experience as a kind of process associated with participants and circumcision. In clause 1, the word "ngurusi" (take care) is a verb that serves as a material process. Whereas in clause 2, the word "kurus" (thin) is an adjective that functions as a verbiage. So in this case, constituent changes occur in 2 clauses with different processes, ie clause 1 uses the material process and clause 2 uses the process of mental behavior.

\section{Participant - Participant}

In this data shows comedian strategies and constituent changing between participant and participant for a same word in Indonesian but has different aim and meaning.

(2.1) "Janganlah bangga menjadi atasan, karena di Pasar Baru, atasan 10 ribu dapet 3." (Do not be proud to be a boss, because in Pasar Baru, top 10 thousand get 3.) 
C1: Janganlah bangga menjadi atasan,

(Do not be proud to be a $\underline{\text { boss }}$,)

(goal)

C2: karena di Pasar Baru, atasan 10 ribu dapet 3.

aktor

(because in Pasar Baru, top (cloth) 10 thousand get 3.)

(actor)

Suhadi (1989) said that humor will present a funny thing, depending on the selection of sounds/intonations, meanings, and contradictions or misappropriation of certain rules, customs or cultures. The general structure are; orientation is the opening of humor material that introduces the thing to be highlighted, event is the explanation of the occurrence of an event in the series of humor material, then twist is the ending or end of a story that is usually deliberately twisted or deflected to get funny. In the data (2.1) the comedian suggested not to be proud to be a "atasan" (boss). The comedian presents the word "bangga" (proud) in an effort to lock the interpretation of the meaning of the listener to the word "atasan" (boss). Thus listeners will interpret the word "atasan" (boss) which refers to "pimpinan" (leader) or (boss). Then the comedian immediately and suddenly distort the meaning of "atasan" (boss) with the reference "pakaian dalam bagian atas wanita" (upper lingerie of women).

Based on Halliday (1985) which emphasizes that internal experience is in consciousness, reaction, understanding, and perception, in addition to its linguistic actions in speaking and understanding. Further detailed in the theory of transitivity as a system that describes experience as a kind of process associated with participants and circumcision. In clause 1, the word "atasan" (boss) serves as a goal, whereas in clause 2, the word "atasan" (upper lingerie of women) acts as an actor. So in this case, the word "atasan" changes the function and meaning that gives surprising because the speaker suddenly distorts the first meaning that should mean the boss or the leader into clothing.

\section{Participant - Circumstance}

In this data shows comedian strategies and constituent changing between participant and ciscumstance for a same word in Indonesian but has different aim and meaning.

(3.1) "Anda tidak ngerti. Salah siapa? Salah itu striker Chelsea. Dia bukan pembajak, bukan penjual, dan bukan pembeli CD bajakan." ("You do not understand. Whose Salah (fault)? Salah is the Chelsea striker. He is not a hijacker, not a seller, and not a buyer of pirated CDs.")

C1: $\underline{\text { Salah siapa? }}$

sirkumstan

(Whose Salah (fault)?

(circumstance)

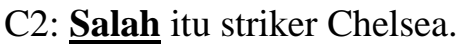
pembawa

(Salah is the Chelsea striker.)

(carrier) 
Suhadi (1989) said that humor will present a funny thing, depending on the selection of sounds/intonations, meanings, and contradictions or misappropriation of certain rules, customs or cultures. The general structure are; orientation is the opening of humor material that introduces the thing to be highlighted, event is the explanation of the occurrence of an event in the series of humor material, then twist is the ending or end of a story that is usually deliberately twisted or deflected to get funny. In the data (3.1) the comedian ask a question "Salah siapa?" (Whose Salah (fault)?). the comedian has made sure the meaning of the word "salah" (wrong/fault) will be interpreted as a mistake maker, because the context of the sentence directs the word "salah" (wrong) to that meaning. However, the comedian immediately and suddenly change the word "salah" (wrong) with reference "tidak benar atau keliru" (incorrect or false) to "nama orang" (person's name). In clause 1 "salah" (wrong) is "pembuat kesalahan" (a mistake maker), while clause 2 "salah" refers to "the name of one of the football team's attacker".

Based on Halliday (1985) which emphasizes that internal experience is in consciousness, reaction, understanding, and perception, in addition to its linguistic actions in speaking and understanding. Further detailed in the theory of transitivity as a system that describes experience as a kind of process associated with participants and circumcision. In clause 1, the word "salah" (wrong) is an annotation that serves as circumstantial, whereas in clause 2; clause 1 is relational process and clause 2 is relational process.

\section{Circumstance - Circumstance}

In this data shows comedian strategies and constituent changing between circumstance and circumstance for a same word in Indonesian but has different aim and meaning.

(4.1) "Kalau anda punya teman kantor cantik sekali, jangan dipacari! Itu rugi. Kan cantiknya cuma sekali, setelah itu enggak." (If you have an office friend's beautiful, do not courted, was a loss. Because her pretty just once, after that, it is not.)

$\mathrm{C} 1$ : Kalau anda punya teman kantor cantik sekali, jangan dipacari! Itu rugi.

sirkumstan

(If you have an office friend who is very beautiful, do not courted, was a loss.)

(circumstance)

C2: Kan cantiknya cuma sekali, setelah itu enggak. sirkumstan

(Because her pretty just once, after that, it is not.) (circumstance)

Suhadi (1989) said that humor will present a funny thing, depending on the selection of sounds/intonations, meanings, and contradictions or misappropriation of certain rules, customs or cultures. The general structure are; orientation is the opening of humor material that introduces the thing to be highlighted, event is the explanation of the occurrence of an event in the series of humor material, then twist is the ending or end of a story that is usually deliberately twisted or deflected to get funny. In the data (4.1) the comedian forbid the listener to make a beautiful girlfriend as a girlfriend. This prohibition will bring disharmony to the listener, because one of the criteria to choose a partner (wife) is beauty for men. Next, the comedian suddenly deviates the meaning of "sekali" (very) with reference "sangat" (very) to "satu kali" (one time/once). At clause 1 "sekali" (very) is "sangat" (very) while clause 2 "sekali" (once) is "satu kali" (one time/once).

Based on Halliday (1985) which emphasizes that internal experience is in consciousness, reaction, understanding, and perception, in addition to its linguistic actions in speaking and 
understanding. Further detailed in the theory of transitivity as a system that describes experience as a kind of process associated with participants and circumcision. In clause 1, the word "sekali" (very) is an adverb that functions as a circumstantial. Whereas in clause 2, the word "sekali" (one time/once) is an adverb functioning as a circumstantial. So in this case, the constituent change takes place in 2 clauses with the same process, ie clause 1 and clause 2 using relational processes.

\section{CONCLUSION}

From all the elaboration and analysis of data in the previous section, it is known that the comedian utilizes looseness and various new meanings that can be embedded in the word. The comedian brings the context of a sentence to direct the interpretation of listeners to a certain meaning. Furthermore, the comedian distorts meaning by presenting a second meaning in an attempt to shock his audience. The comedian utilizes the word meaning relationships include, polysemic (atasan and sekali), and compounded words (ngurusi). In addition, the comedian also changes the word to pronomina persona (salah). The strength of the comedian humor lies in its sensitivity to see the gap of a word, then to present it by trapping the interpreter of the listener in the wrong interpretation of meaning.

Furthermore, in the creation of a humorous language of the comedian focuses on constituent changes made from the experience it possesses. Constituent change occurs in the function; process - participant, participant - participant, participant - circumstance, and circumstance - circumstance. This causes a change of meaning and interpretation for a similar word because the constituent changes that occur also result in a change in word class.

\section{REFERENCES}

Aminuddin, E. (1990). Pengembangan Penelitian Kualitatif dalam Bidang Bahasa dan Sastra. Malang: Yayasan Asih Asah Asuh \& HISKI.

Fauzan, U. (2015). Transitivitas Teks Berita Tv One Mengenai Kasus Luapan Lumpur Sidoarjo. Jurnal PEDAGOGIK, 8(1), 234-240.

Firmansyah, M. B. (2017). Representasi Bahasa Humor dalam Acara Stand Up Comedy di Metro TV. KEMBARA: Jurnal Keilmuan Bahasa, Sastra, dan Pengajarannya, 2(2), 195-202.

Halliday, M. (1985). Systemics Background. In J. D. Benson \& W. S. Greaves (Eds.), Systemic Perspective on Discourse. Nor wood: Ablex Publishing.

Halliday, M., Matthiessen, C., \& Halliday, M. (2014). An Introduction to Functional Grammar. New York: Routledge.

Juramli, J. (2016). Transivitas pada Teks Daqaaiqul Akhbar Telaah Fungsi Ideasional dalam Kajian Linguistik Fungsional Sistemik LITERA: Jurnal Litera Bahasa dan Sastra, 1(2), 130-141.

Mahsun, M. (2014). Metode Penelitian Bahasa: Tahapan Strategi, Metode dan Tekniknya: Yogyakarta: PT Raja Grafindo Persada.

Marwan, I. (2013). Wujud Kebahasaan dalam Wacana Humor Kajian Semiotika. Jurnal AlTsaqafa, 10(1), 78-89.

Moleong, L. (2013). Metodologi Penelitian Kualitatif. Bandung: PT. Remaja Rosdakarya.

Mujianto, G. (2018). Analisis Wacana Kritis Pemberitaan Tentang Ormas Islam pada Situs Berita Online. Kembara, 4(2), 155-172.

Poerdawarminta, W. J. S. (2002). Kamus Besar Bahasa Indonesia. Jakarta: Balai Pustaka. 
Rohmadi, M. (2010). Strategi Penciptaan Humor dengan Pemanfaatan Aspek-Aspek Kebahasaan. Humaniora, 22(3), 285-298.

Soedjatmiko, W. (1992). Pellba 5. Yogyakarta: Kanisius.

Sugiyono, P. (2014). Metode Penelitian Kuantitatif dan Kualitatif dan R\&D. Bandung: Alfabeta.

Suhadi, A. (1989). Humor Itu Serius: Pengantar ke" Ilmu Humor". Jakarta: Pustakakarya Grafikatama.

Tiani, R. (2017). Strategi Pragmatik dalam Penciptaan Humor di Televisi. NUSA, 12(2), 42-51. 